\title{
Accounting Information and Managerial Decision Making in the Manufacturing Industry in Nigeria
}

\author{
Lawal Babatunde Akeem \\ Department of Accounting \& Finance, \\ McPherson University, Ogun State \\ Ayooluwa Olotu Ajayi-Owoeye \\ Department of Accounting, \\ Babcock University, Ilisan, Ogun State \\ Oyetunji Oluwayomi \\ Department of Accounting, \\ Babcock University, Ilishan, Ogun State \\ Odusina Ayokunle Olumide \\ Department of Banking \& Finance, \\ Abraham Adesanya Polytechnic, Ijebu-Igbo, Ogun State
}

\begin{abstract}
In the contemporary business world, the role of accounting information in making or marring a business cannot be overemphasized. Recent worldwide advances in manufacturing technologies have brought about a metamorphosis in industry. This paper established the relationship between accounting information and managerial decision making in the manufacturing industry in Nigeria. The study was guided by the following research objectives; to establish the relationship that exists between accounting information and production decisions; to evaluate the relationship that exists between accounting information and human resource management decisions and to assess the relationship that exists between accounting information and marketing decisions in the Nigerian manufacturing sector. The research design adopted for this study is the survey design. The population of the study comprised of the eight companies in beverage sector of the manufacturing industry in Nigeria. The survey research made use of Seven Up Bottling Company Plc, and Nigeria Bottling Company as representatives of the manufacturing industry. Primary data was collected through administering of questionnaire to the staff of the companies. The sample size of the study was $\mathbf{3 8 2}$ derived from the Yaro Yamani's formula. Based on the findings, it was concluded that accounting information has an effect on managerial decision making in the Nigerian manufacturing industry. The study recommended that due to the importance of human capital in any organisation, promotion, transfer and retrenchment decisions should be handled with utmost sensitivity. Also, accounting information should therefore be inculcated into the taking of such decisions as it will affect the human resource management department and the organisation as a whole if the wrong decision is taken.
\end{abstract}

Keywords: accounting information, technologies, managerial decision, marketing decision, organization, and human resource management.

\section{INTRODUCTION}

In the contemporary business world, the role of accounting information in making or marring a business cannot be over-emphasized. Accounting is generally attributed to collecting, 
recording, analyzing and interpreting all transactions of a firm. Accounting must be understood as a system of information that measures the activity of a firm and processes this information in such a way that it is easily communicated to and understood by the final users. It must allow these users to make value judgments about the financial situation of firms and organizations and also about their activity in order to make informed decisions regarding their future (Costa, 2012).

According to the American Institute of Certified Public Accountants (1966), accounting actually is information system and to be more precise, accounting is the practice of general theories of information in the field of effective economic activities and consists of a major part of the information which is presented in the quantitative form. Accounting is believed to give a general view of the health of an organisation and is therefore important in the process of making decisions. It is referred to as the language of business as it communicates the results of business activities.

The world is now basically consumer-driven which means that manufacturing companies should be ready to innovate and develop new products to stay relevant. As companies vie to be first to market with a new concept, the temptation to compromise on quality can be huge, however manufacturers need to be stringent and avoid cutting corners. Fast times to market mean that companies need to become more structured in their approach to managing innovation - great product ideas cannot be left to chance. Implementing procedures that keep a steady stream of new product ideas and innovations in the pipeline is essential to manufacturing success.

Manufacturing is the backbone of any industrialized nation. Recent worldwide advances in manufacturing technologies have brought about a metamorphosis in industry. Fast-changing technologies on the product front have created a need for an equally fast response from manufacturing industries. The current economy coupled with rapidly changing technology, rising labour and production costs, and new regulations make it difficult for manufacturers to maintain margins and remain profitable in the market place. To meet these challenges, manufacturing industries have to select appropriate manufacturing strategies, product designs, manufacturing processes, work piece and tool materials, and machinery and equipment. The selection decisions are complex, as decision making is more challenging today.

The main objective of this paper is to ascertain the relationship which exists between accounting information and managerial decision making in the Nigerian manufacturing industry. Other specific are to:

- Establish the relationship that exists between accounting information and production decisions in the Nigerian manufacturing sector.

- Evaluate the relationship that exists between accounting information and human resource management decisions in the Nigerian manufacturing sector.

- Assess the relationship that exists between accounting information and marketing decisions in the Nigerian manufacturing sector.

\section{Theoretical Review}

\section{Agency Theory}

Agency theory was developed by Jensen and Meckling in 1976. They suggested a theory of how the governance of a company is based on the conflicts of interest between the company's owners (shareholders), its managers and major providers of debt finance (Institute of Chartered Accountants of Nigeria, 2014). 
During the 1960s and early 1970s, economists explored risk sharing among individuals or groups. This literature described the risk-sharing problem as one that arises when cooperating parties have different attitudes toward risk. Agency theory broadened this risk-sharing literature to include the so-called agency problem that occurs when cooperating parties have different goals and division of labour (Jensen \& Meckling, 1976; Ross, 1973). Specifically, agency theory is directed at the ubiquitous agency relationship, in which one party (the principal) delegates work to another (the agent), who performs that work. Agency theory attempts to describe this relationship using the metaphor of a contract (Jensen \& Meckling, 1976).

\section{Information Theory}

Information theory was initially introduced in 1948 by Claude Shannon. The first half of the 20 th century brought about a revolution in how humans think about information. Claude Shannon (the father of modern information theory) was at the forefront of this revolution. His landmark 1948 paper, A Mathematical Theory of Communication, was the first paper to formally describe a communication system in which information plays a central role. Concepts such as the capacity of an information channel, uncertainty of a source and the optimal rate of information transmission in a noisy environment revolutionized how we think about information. These concepts laid the groundwork for much of the technology and the optimal rate of information transmission in a noisy environment revolutionized how we think about information. According to Shannon, the problem of communication is that of reproducing at one point, either exactly or approximately, a message selected at another point. Frequently the messages have meaning; that is they refer to or are correlated according to some system with certain physical or conceptual entities.

\section{Conceptual Review}

According to Kombo and Tromp (2006), a concept is an abstract or general idea inferred or derived from specific instances. The independent variable of the study is accounting information and the dependent variables include production decisions, human resource management decisions and marketing decisions.

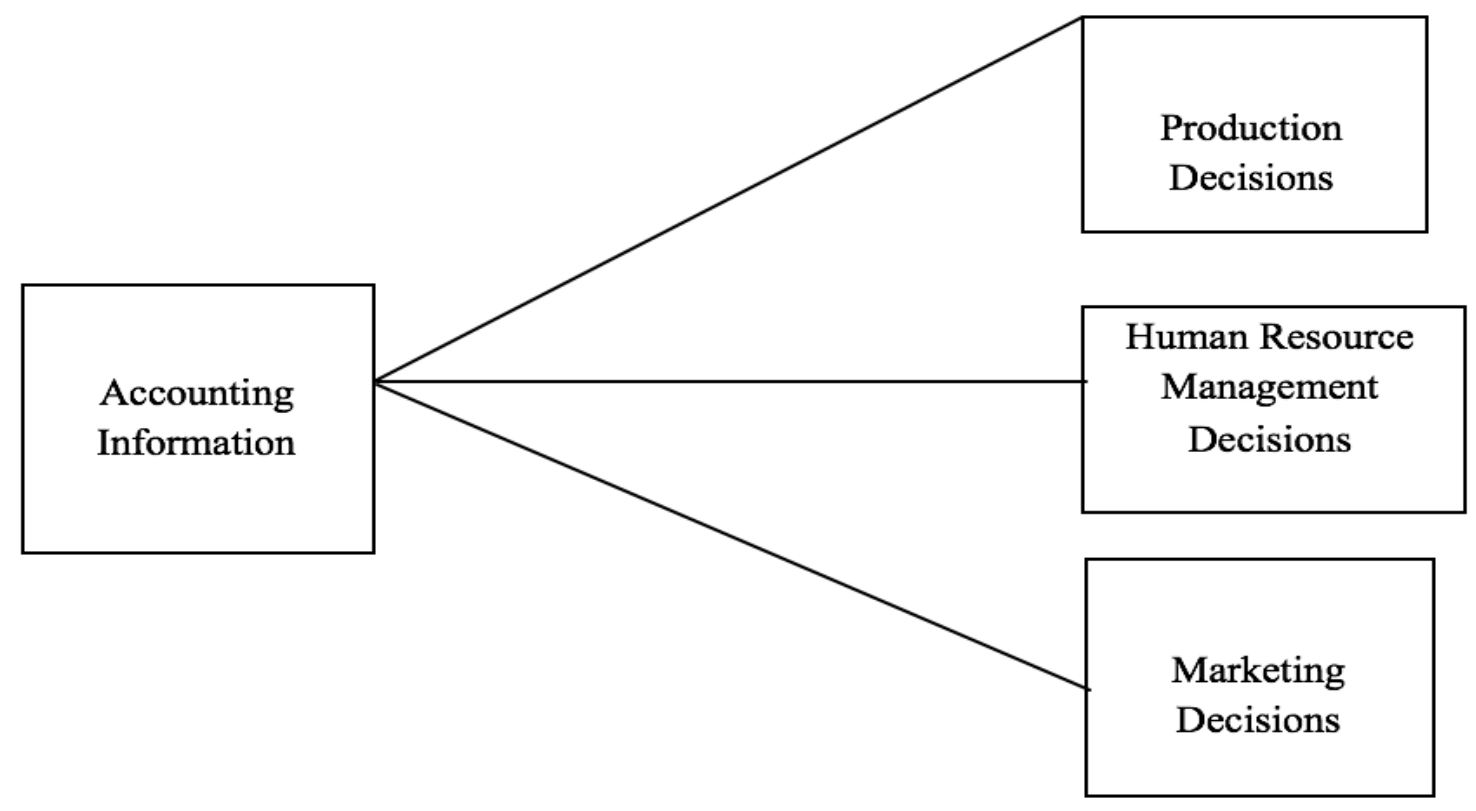

Independent Variable

Dependent Variables

Figure 2.1 Conceptual Model 


\section{Review of Empirical Studies}

According to Hopwood (1974), accounting systems serve two purposes in the decision process. First, they provide stimuli by which problems are both recognised and defined, and the alternative courses of action are isolated and their consequences elaborated. Secondly, accounting helps to analyse and appraise alternatives. Horngren, Sundem and Stratton (2002) see the main function of accounting information in its aid in the decision-making process, as the understanding of accounting information contributes to better decisions. So, by reporting and collecting accounting information, controllers can influence management's decisionmaking and lead them towards decisions that are in accordance with the organisation's objectives.

According to Anthony (1989) and Sharman (2003), the management accountants, using the management accounting system including the performance measurement system, support manufacturing and influence the manufacturing decisions in order to align them with the company's general strategy. Pantamee, Abubakar and Umar (2008), in their study on the relevance of management accounting information towards decision making in Nigerian manufacturing industry stated that "good decisions are to be made by management section using management accounting information, short-term tactical decision like: Make or buy decision, elimination of unprofitable product, allocation of scarce resources between competing product or departments, acceptance or rejection of an offer etc. All these are to be made by management using managerial costing techniques as a management accounting tool. In a study conducted by Al-Raber, Abu-Taber, Alaryan and Ayaman (2015), on the role of accounting information system in enhancing human resource management cycle in Jordanian Islamic banks, it was established that accounting information plays a significant role in some human resource management functions such as hiring functions, training functions, performance evaluation functions and compensation functions.

In a study on the impact human resource accounting information on managerial decisions (Pekin, 1988), the results of a field experiment designed to assess the impact of human resource accounting (HRA) information on layoff decisions made by managers was analysed. The findings of this study are similar to the earlier studies; human resource accounting information does make a difference in personnel layoff decisions and enables managers to increase their level of confidence regarding decisions of this sort.

Another study in the subject area maintains that accounting must be considered in the realm of management strategies. According to Dunkovic, Juric and Nikolic (2010), activity based cost management using conventional accounting methods, as well as current approaches such as target cost systems, customer lifetime value and computer supported measurement techniques must be used to measure the performance of especially customers, suppliers and competitors.

Adela, Crina, and Anuţa (2008) in their study on means for measuring the quality of the accounting information, it was concluded that accounting system and especially managerial accounting provide useful information for decision making. Information is the product of accounting and that means that the quality of accounting information influences the quality of decisional process that will influence the customers' satisfaction. Adela et al (2008), further went ahead to state that "the development of accounting information to support marketing decisions making in hotels offers opportunities to improve the quality of decisions made".

\section{METHODOLOGY}

The research design adopted for this study is the survey design. The design was used to examine the effect of accounting information on managerial decision making in the 
manufacturing industry of Nigeria. The population of the study comprised of the eight companies in beverage sector of the manufacturing industry in Nigeria. The survey research made use of Seven Up Bottling Company Plc, and Nigeria Bottling Company as representatives of the manufacturing industry. For the purpose of this research the purposive sampling method was used to select the sample. There are approximately 4,800 employees in the Nigerian Bottling Company and 3,500 in Seven Up Bottling Company Plc as at 2016. To determine the sample size the Yaro Yamani's formula was used.

Where $\mathrm{n}=$ Desired sample size

$$
\mathrm{n}=\frac{\mathrm{N}}{1+\mathrm{N}(\mathrm{e})^{2}}
$$

$\mathrm{N}=$ Size of population

$\mathrm{e}=$ limit of error tolerance which was assured to be $5 \%(0.05)$ confidence limit

$$
\begin{aligned}
& \mathrm{n}=\frac{8300}{1+8300(0.05)^{2}} \\
& \mathrm{n}=\frac{8300}{1+8300(0.0025)} \\
& \mathrm{n}=\frac{8300}{1+8300(0.0025)} \\
& \mathrm{n}=\frac{8300}{1+20.75} \\
& \mathrm{n}=\frac{8300}{21.75} \\
& \mathrm{n}=382
\end{aligned}
$$

Primary data was collected through administering of questionnaire to the staff of the companies. The questionnaire was administered to 382 individuals and 277 were retrieved. The questionnaire so designed was administered to the staff of the Nigerian Bottling Company and Seven Up Bottling Company Plc. The percentage of retrieved questionnaire to the administered is $73 \%$.

\section{Model Specification}

This research attempts a numeric measure of the effect of accounting information and managerial decision making. Thus, we specify a model of an assumed functional relationship between accounting information in the Nigerian manufacturing industry at one end, and the managerial decision making on the other end. This is to enable us to examine the effect of accounting information on decision making by managers. To achieve this, we consider these indicators. The linear relationship between the dependent and independent variable in this study is functionally expressed thus:

$$
Y=f(X)
$$

Where $\mathrm{Y}=$ managerial decision making (dependent variable)

$\mathrm{f}=$ functional relationship

$\mathrm{X}=$ accounting information (independent variable)

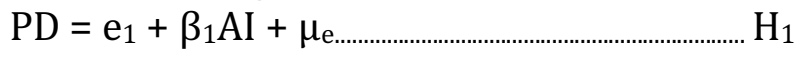

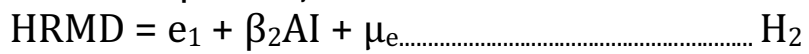

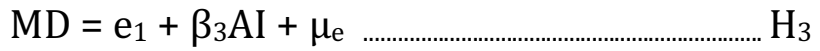

Where $\mathrm{PD}=$ Production decisions

HRMD = Human Resource Management Decisions 
$\mathrm{MD}=$ Marketing Decisions

$\mathrm{e}_{1}=$ Constant

$\beta_{1}, \beta_{2}, \beta_{3}=$ Model Coefficient

$\mu_{\mathrm{e}}=$ Error term

\section{RESULTS AND DISCUSSION}

This section presents the data presentation, analysis and interpretation of socio-demographic characteristics of the respondents and other variables that are of importance to the study.

\section{Percentage Distribution of Respondents on Production Decision Opinions}

This section assessed the relationship between accounting information and production decisions.

Table 4.1 Accounting information in production equipment related decisions

\begin{tabular}{|l|c|c|c|c|}
\hline Response & Frequency & $\begin{array}{c}\text { Percentage } \\
(\%)\end{array}$ & $\begin{array}{c}\text { Valid } \\
\text { Percentage (\%) }\end{array}$ & $\begin{array}{c}\text { Cumulative } \\
\text { Percentage (\%) }\end{array}$ \\
\hline Strongly disagree & 1 & 0.4 & 0.4 & 0.4 \\
\hline Disagree & 4 & 1.4 & 1.4 & 1.8 \\
\hline Fairly agree & 20 & 7.2 & 7.2 & 9.0 \\
\hline Agree & 169 & 61.0 & 61.0 & 70.0 \\
\hline Strongly agree & 83 & 30.0 & 30.0 & 100.0 \\
\hline Total & 277 & 100.0 & 100.0 & \\
\hline
\end{tabular}

Source: Author's Computation, 2019

The table above revealed that $30 \%$ of the respondents strongly agree that the use of accounting information in production equipment related decisions will enhance the production of the company, $61 \%$ agree, $7.2 \%$ fairly agree, $1.4 \%$ disagree, $0.4 \%$ disagrees.

Table 4.2 Accounting information in production planning and cost control decisions

\begin{tabular}{|l|c|c|c|c|}
\hline Response & Frequency & $\begin{array}{c}\text { Percentage } \\
(\%)\end{array}$ & $\begin{array}{c}\text { Valid } \\
\text { Percentage (\%) }\end{array}$ & $\begin{array}{c}\text { Cumulative } \\
\text { Percentage (\%) }\end{array}$ \\
\hline Fairly agree & 2 & 0.7 & 0.7 & 0.7 \\
\hline Agree & 169 & 61.0 & 61.0 & 61.7 \\
\hline $\begin{array}{l}\text { Strongly } \\
\text { agree }\end{array}$ & 106 & 38.3 & 38.3 & 100.0 \\
\hline Total & 277 & 100.0 & 100.0 & \\
\hline
\end{tabular}

Source: Author's Computation, 2019

Table 4.2 revealed that $4.4,38.3 \%$ strongly agree that the use of accounting information in production planning and control decisions will guide against stock out and loss of customers, $61 \%$ agree while $0.7 \%$ fairly agrees.

\section{Percentage Distribution of respondents on Human Resource Management Decision}

This section presents the respondents opinion on accounting information and human resource management decisions. 
Table 4.3 Accounting information on human resource policies

\begin{tabular}{|l|c|c|c|c|}
\hline Response & Frequency & $\begin{array}{c}\text { Percentage } \\
(\%)\end{array}$ & $\begin{array}{c}\text { Valid } \\
\text { Percentage (\%) }\end{array}$ & $\begin{array}{c}\text { Cumulative } \\
\text { Percentage (\%) }\end{array}$ \\
\hline Disagree & 7 & 2.5 & 2.5 & 2.5 \\
\hline Fairly agree & 25 & 9.1 & 9.1 & 11.6 \\
\hline Agree & 192 & 69.3 & 69.3 & 80.9 \\
\hline $\begin{array}{l}\text { Strongly } \\
\text { agree }\end{array}$ & 53 & 19.1 & 19.1 & 100.0 \\
\hline Total & 277 & 100.0 & 100.0 & \\
\hline
\end{tabular}

Source: Author's Computation, 2019

From table 4.3 above, 19.1\% strongly agree that the use of accounting information in human resource policies will help in the employment of quality staff, $69.3 \%$ agree, $9 \%$ fairly agree while $2.5 \%$ of the respondents disagree.

Table 4.4 Accounting information in promotion transfer, and retrenchment related decisions

\begin{tabular}{|l|c|c|c|c|}
\hline Response & Frequency & $\begin{array}{c}\text { Percentage } \\
(\%)\end{array}$ & $\begin{array}{c}\text { Valid } \\
\text { Percentage (\%) }\end{array}$ & $\begin{array}{c}\text { Cumulative } \\
\text { Percentage (\%) }\end{array}$ \\
\hline Disagree & 8 & 2.9 & 2.9 & 2.9 \\
\hline Fairly agree & 24 & 8.7 & 8.7 & 11.6 \\
\hline Agree & 196 & 70.7 & 70.7 & 82.3 \\
\hline Strongly agree & 49 & 17.7 & 17.7 & 100.0 \\
\hline Total & 277 & 100.0 & 100.0 & \\
\hline
\end{tabular}

\section{Source: Author's Computation, 2019}

From table 4.4 above, $17.7 \%$ strongly agree that the use of accounting information in promotion, transfer and retrenchment related decisions will help to guide against staff turnover, $70.7 \%$ agree, $8.7 \%$ fairly agree and $2.9 \%$ of the respondents disagree

\section{Percentage Distribution of Respondents on Marketing Decisions}

This section presents the data on the respondents' opinion regarding accounting information and marketing decisions.

Table 4.5 Use of accounting information in selling and marketing decisions such as using agents or dealers will enhance sales turnover

\begin{tabular}{|c|c|c|c|c|}
\hline Response & Frequency & Percentage (\%) & Valid Percent (\%) & Cumulative Percent (\%) \\
\hline Disagree & 2 & 0.7 & 0.7 & 0.7 \\
\hline Fairly agree & 28 & 10.1 & 10.1 & 10.8 \\
\hline Agree & 160 & 57.8 & 57.8 & 68.6 \\
\hline $\begin{array}{c}\text { Strongly } \\
\text { agree }\end{array}$ & 87 & 31.4 & 31.4 & 100.0 \\
\hline Total & 277 & 100.0 & 100.0 & \\
\hline
\end{tabular}

Source: Author's Computation, 2019 
Table 4.5 revealed that $31.4 \%$ strongly agree that the use of accounting information in selling and marketing decisions such as using agents or dealers will enhance turnover, $57.8 \%$ agree, $10.1 \%$ fairly agree and $0.7 \%$ disagrees.

Table 4.6 Accounting information in promotional policy decisions

\begin{tabular}{|l|c|c|c|c|}
\hline Response & Frequency & $\begin{array}{c}\text { Percentage } \\
(\%)\end{array}$ & $\begin{array}{c}\text { Valid } \\
\text { Percentage (\%) }\end{array}$ & $\begin{array}{c}\text { Cumulative } \\
\text { Percentage (\%) }\end{array}$ \\
\hline Disagree & 25 & 9.0 & 9.0 & 9.0 \\
\hline Fairly agree & 55 & 19.9 & 19.9 & 28.9 \\
\hline Agree & 135 & 48.7 & 48.7 & 77.6 \\
\hline $\begin{array}{l}\text { Strongly } \\
\text { agree }\end{array}$ & 62 & 22.4 & 22.4 & 100.0 \\
\hline Total & 277 & 100.0 & 100.0 & \\
\hline
\end{tabular}

Source: Author's Computation, 2019

From table 4.6 above, $22.4 \%$ strongly agree that the use of accounting information in promotional policy decisions such as advertising will ensure the acceptability of the product in the market, $48.7 \%$ agree, $19.9 \%$ fairly agree and 9\% disagree.

\section{Testing of Hypotheses}

\section{Hypothesis One}

$\mathbf{H}_{\mathbf{0}}$ : There is no significant relationship between accounting information and production decisions.

To test this hypothesis, linear regression method was adopted. The results and conclusions are explained below.

Table 4.7 Model Summary One

\begin{tabular}{|l|l|l|l|l|}
\hline Model & $\mathrm{R}$ & R Square & $\begin{array}{l}\text { Adjusted } \\
\text { Square }\end{array}$ & $\begin{array}{l}\text { Std. Error of } \\
\text { the Estimate }\end{array}$ \\
\hline 1 & $.530^{\mathrm{a}}$ & .280 & .278 & .42477 \\
\hline
\end{tabular}

a. Predictors: (Constant), Accounting Information

Table 4.7 shows the result from the analysis that relationship exists between the independent variable and the dependent variable. The model was significant by establishing a relationship between accounting information and production decisions. The coefficient of determination $\left(\mathrm{R}^{2}\right)$ is 0.280 , which indicates that 28 percent of the variations in production decisions were explained by the independent variable which is accounting information. Therefore, it is concluded that for Hypothesis one that, there is a significant relationship between accounting information and production 
Table 4.8 Regression Result for Model One

\begin{tabular}{|c|c|c|c|c|c|c|}
\hline \multirow[t]{2}{*}{ Model } & & \multicolumn{2}{|c|}{$\begin{array}{l}\text { Un-standardised } \\
\text { Coefficients }\end{array}$} & \multirow{2}{*}{$\begin{array}{c}\begin{array}{c}\text { Standardised } \\
\text { Coefficients }\end{array} \\
\text { Beta }\end{array}$} & \multirow[t]{2}{*}{$\mathrm{T}$} & \multirow[t]{2}{*}{ Sig. } \\
\hline & & $\mathrm{B}$ & Std. Error & & & \\
\hline \multirow[b]{2}{*}{1} & (Constant) & 2.061 & 0.225 & & 9.156 & 0.000 \\
\hline & $\begin{array}{l}\text { Accounting } \\
\text { Information }\end{array}$ & 0.529 & 0.051 & 0.530 & 10.352 & 0.000 \\
\hline
\end{tabular}

a. Dependent Variable: Production Decision

$\mathrm{PD}=2.061+0.529 \mathrm{AI}+\mu_{\mathrm{e}}$

From table 4.8 above, the constant gave a value 2.061 which is the intercept, hence establishing a positive relationship because of the positive value while the row contains the name of the Independent Variable (Accounting Information) which refers to the slope. The table also shows the $t$ statistics which helped to determine the relative importance of each variable in the model and this is known by the independent variable. The value for the independent variable is statistically significant; this also explains the establishment of a relationship between the independent variable and the dependent variable. The independent variable (Accounting Information) had a significant value of 0.000 which is lower than the decision rule value of 0.05 $(p<0.05)$ and this explains for the strong relationship that existed among the variables. Therefore, it is concluded that there is significant relationship between accounting information and production decisions in the Nigerian manufacturing sector.

Based on this, the null hypothesis is rejected and the alternative hypothesis accepted.

\section{Hypothesis Two}

$\mathbf{H}_{\mathbf{0}}$ : There is no significant relationship between accounting information and human resource management decisions.

This hypothesis was tested using the linear regression model. The results and conclusions are explained below.

Table 4.9 Model Summary Two

\begin{tabular}{|l|l|l|l|l|}
\hline Model & $R$ & R Square & $\begin{array}{l}\text { Adjusted R } \\
\text { Square }\end{array}$ & $\begin{array}{l}\text { Std. Error of } \\
\text { the Estimate }\end{array}$ \\
\hline 1 & $0.469^{a}$ & 0.220 & 0.217 & 0.57006 \\
\hline
\end{tabular}

a. Predictors: (Constant), Accounting Information

Table 4.9 shows the result from the analysis that relationship exists between the independent variable and the dependent variable. The model was significant by establishing a relationship between accounting information and human resource management decisions. The coefficient of determination $\left(\mathrm{R}^{2}\right)$ is 0.220 , which indicates that 22 percent of the variations in human resource management decisions were explained by the independent variable which is accounting information. Therefore, it is concluded that for Hypothesis two that, there is a significant relationship between accounting information human resource management decisions. 
Table 4.10 Regression Result for Model Two

\begin{tabular}{|l|l|c|c|c|c|c|}
\hline \multirow{2}{*}{ Model } & & \multicolumn{2}{|c|}{$\begin{array}{c}\text { Un-standardised } \\
\text { Coefficients }\end{array}$} & $\begin{array}{c}\text { Standardised } \\
\text { Coefficients }\end{array}$ & \multirow{2}{*}{ T } & \\
\cline { 3 - 5 } & & $\mathrm{B}$ & Std. Error & Beta & & \\
\hline \multirow{3}{*}{1} & (Constant) & 2.294 & 0.201 & & 11.399 & 0.000 \\
\cline { 2 - 7 } & $\begin{array}{l}\text { Accounting } \\
\text { Information }\end{array}$ & 0.435 & 0.049 & 0.469 & 8.805 & 0.000 \\
\hline
\end{tabular}

a. Dependent Variable: Human Resource Management Decisions

$\mathrm{HRMD}=2.294+0.435 \mathrm{AI}+\mu_{\mathrm{e}}$

From table 4.10 above, the constant gave a value 2.294 which is the intercept, hence establishing a positive relationship because of the positive value while the row contains the name of the Independent Variable (Accounting Information) which refers to the slope. The table also shows the $t$ statistics which helped to determine the relative importance of each variable in the model and this is known by the independent variable. The value for the independent variable is statistically significant, this also explain the establishment of a relationship between the independent variable and the dependent variable. The independent variable (Accounting Information) had a significant value of 0.000 which is lower than the decision rule value of $0.05(\mathrm{p}<0.05)$ and this explains for the strong relationship that existed among the variables. Therefore, it is concluded that there is significant relationship between accounting information and human resource management decisions in the Nigerian manufacturing sector.

Based on this result, the null hypothesis is rejected and the alternative hypothesis accepted.

\section{Hypothesis Three}

$\mathrm{H}_{0}$ : There is no significant relationship between accounting information and marketing decisions.

This hypothesis was tested using the linear regression model. The results and conclusions are explained below.

Table 4.11 Model Summary Three

\begin{tabular}{|l|l|l|l|l|}
\hline Model & $\mathrm{R}$ & R Square & $\begin{array}{l}\text { Adjusted } \\
\text { Square }\end{array}$ & $\begin{array}{l}\text { Std. Error of } \\
\text { the Estimate }\end{array}$ \\
\hline 1 & $0.572^{\mathrm{a}}$ & 0.327 & 0.325 & 0.55851 \\
\hline
\end{tabular}

a. Predictors: (Constant), Accounting Information

Table 4.11 shows the result from the analysis that relationship exists between the independent variable and the dependent variable. The model was significant by establishing a relationship between accounting information and marketing decisions. The coefficient of determination $\left(\mathrm{R}^{2}\right)$ is 0.327 , which indicates that 32.7 percent of the variations in production decisions were explained by the independent variable which is accounting information. Therefore, it is concluded that for Hypothesis three that, there is a significant relationship between accounting information and marketing decisions. 
Table 4.12

Regression Result for Model Three

\begin{tabular}{|c|c|c|c|c|c|c|}
\hline \multirow[t]{2}{*}{ Model } & & \multicolumn{2}{|c|}{$\begin{array}{l}\text { Un-standardised } \\
\text { Coefficients }\end{array}$} & $\begin{array}{c}\text { Standardised } \\
\text { Coefficients }\end{array}$ & \multirow[t]{2}{*}{$\mathrm{T}$} & \multirow[t]{2}{*}{ Sig. } \\
\hline & & B & Std. Error & Beta & & \\
\hline \multirow[b]{2}{*}{1} & (Constant) & 2.253 & 0.158 & & 14.215 & 0.000 \\
\hline & $\begin{array}{l}\text { Accounting } \\
\text { Information }\end{array}$ & 0.451 & 0.039 & 0.572 & 11.562 & 0.000 \\
\hline
\end{tabular}

a. Dependent Variable: Marketing Decisions

$\mathrm{MD}=2.253+0.451 \mathrm{AI}+\mu_{\mathrm{e}}$

From table 4.12 above, the constant gave a value 2.253 which is the intercept, hence establishing a positive relationship because of the positive value while the row contains the name of the Independent Variable (Accounting Information) which refers to the slope. The table also shows the $t$ statistics which helped to determine the relative importance of each variable in the model and this is known by the independent variable. The value for the independent variable is statistically significant; this also explains the establishment of a relationship between the independent variable and the dependent variable. The independent variable (Accounting Information) had a significant value of 0.000 which is lower than the decision rule value of $0.05(\mathrm{p}<0.05)$ and this explains for the strong relationship that existed among the variables. Therefore, it is concluded that there is significant relationship between accounting information and marketing decisions in the Nigerian manufacturing sector.

Based on this result, the null hypothesis is rejected and the alternative hypothesis accepted

\section{DISCUSSION OF FINDINGS}

The purpose of this study was to examine accounting information and its effect on managerial decision making in the Nigerian manufacturing industry. Primary data was used for the analysis.

The regression result of model one reveals a linear regression result of the independent variable (accounting information) on the dependent variable (production decisions). The result showed that there is a significant relationship between accounting information and production decisions. This result follows the study of Pantamee et al (2008). The findings of their research work led them to conclude that there is a significant relationship between management accounting information and managerial decision making in the manufacturing industry. Decisions like make or buy decisions, elimination of unprofitable products, purchase of equipment, etc require accounting information. Jawabreh and Al-rabei (2012), in their study on the impact of accounting information system in planning, controlling and decision making in Jodhpur hotels concluded that there is no relationship between Accounting Information System and Decision Making in four and five - star Jodhpur Hotels. The result explained that accounting information is not used to make production decisions, or to make informed economic decisions. This differs from the findings of this research study.

The regression result of model two revealed a linear regression result of the independent variable on the dependent variable. The result shows that there is a significant relationship between accounting information and human resource management decisions. In Pekin 1988's field experiment it was concluded that accounting information gotten from human resource accounting will help in personnel layoff decisions (retrenchment) and give confidence to managers regarding such decisions. This is in support of the findings of this research work in regards to promotion, transfer and retrenchment related decisions. This result is further explained by the findings of Al-raber et al (2015). This study highlighted the importance of 
using accounting information systems in enhancing the human resources management cycle (i.e. hiring function, training function, performance evaluation function, and compensation function).

The regression result of model three shows that there is a significant relationship between accounting information and marketing decisions. This is supported by the research study of Dumitrana et al (2008) where it was discovered that the development of accounting information to support marketing decisions will improve the quality of decisions taken. The findings of Jawabreh and Al-rabei (2012), differs from the result gotten in this research work. The result explained that accounting information is not used to make marketing decisions as well as production decisions, or to make informed economic decisions. This differs from the findings of this study.

\section{CONCLUSION AND RECOMMENDATIONS}

The study concluded that there exists a significant relationship between accounting information and managerial decision making in the Nigerian manufacturing industry. The study recommended that due to the importance of human capital in any organisation, promotion, transfer and retrenchment decisions should be handled with utmost sensitivity. Also, accounting information should therefore be inculcated into the taking of such decisions as it will affect the human resource management department and the organisation as a whole if the wrong decision is taken. Fast responses are required for problems facing manufacturing companies. Any problem regarding the marketing of products should be handled very quickly but also with quality. Selling and marketing decisions are the backbone of the marketing department and the use of accounting information will ensure the quality of marketing decisions and help companies to control a large percentage of the market. Accounting information can be used to determine what strategies to adopt and how carefully to implement them. The Manufacturers Association of Nigeria (MAN) can adopt strict policies on the production of accounting information in order to ensure that effective decisions are taken in the manufacturing sector.

\section{References}

Adela, D., Crina, F., Anuţa, B. (2008). Means for Measuring the Quality of the Accounting Information. Journal of Accounting and Management Information Systems, 1,(24), 41-57.

Ali M. Al-rabei., Thaer A. Abu Taber., Laith A. Alaryan., \& Ayman A. Abu Haija. (2015). The Role of Accounting Information System in enhancing Human Resources Management Cycle in Jordanian Islamic Banks an Empirical Study. Australian Journal of Basic and Applied Science, 9(20), 437-441.

American Institute of Certified Public Accountants. (1966). Statement of basic accounting theory. New York: AICPA Publication.

Anthony, R. (1989). Reminiscences about Management Accounting. Journal of Management Accounting Research , 1 (1), 1-20.

Costa, J. A. (2012). Accounting: An Information System for Organizations: An Introduction to the Concepts, Methods and Uses of Accounting). Universitat Pompeu Fabra, Department of Economics and Business First edition: February.

Dunković, D., Jurić, Đ., \& Nikolić, T. (2010). Marketing Aspects In Strategic Management Accounting. Interdisciplinary Management Research IV , 739-750.

Hopwood, A. Accounting and human behaviour. London: Haymarket Publishing Limited.

Horngren, C. T., Sundem, G. L., \& Stratton, W. O. (2002). Introduction to management accounting (12 ${ }^{\text {th }}$ ed.). New Jersey: Prentice-Hall International.

Institute of Chartered Accountants of Nigeria. (2014). Financial reporting (1 ${ }^{\text {st }}$ ed.). Berkshire, United Kingdom: Emile Woolf International. 
Institute of Chartered Accountants of Nigeria. (2014). Management, governance and ethics (1 ${ }^{\text {st }}$ ed.). Berkshire, United Kingdom: Emile Woolf International.

Jawabreh, O. A., \& Al-rabei, A. M. (2012). The impact of accounting information system in planning, controlling and decision-making processes in Jodhpur hotels. Asian Journal of Finance \& Accounting , 4 (1), 173-188.

Jensen, M. C., \& Meckling, W. H. (1976). A theory of the firm; Governance, residual claims and organisational forms. Journal Financial Economies, 3(4), 305-360.

Jensen, M., \& Meckling, W. (1976). Theory of the firm: Managerial behaviour, agency costs and ownership structure. Journal of Financial Economics, 3(4), 305-360.

Kombo, D. K., \& Tromp, L., A. (2006). Proposal and Thesis Writing: An Introduction Nairobi: Paulines Publications Africa.

Pantamee, A., Abubakar, A., \& Umar, B. (2008). Retrieved April 20, 2016, from

Academia.edu:https;//www.academia.edu/8057248/the relevance of Manangement Accounting Information toward Decision Making in Nigeria Manufacturing Industry.

Pekin, O. (1988). Assessing the Impact of Human Resource Accounting Information on Managerial Decisions: A Field Experiment, Personnel Review, 17(3), 29-35.

Ross, S. A. (1973). The economic theory of agency: The principal's problem. American Economic Review, 6 (2), 134-139.

Sharman, P., A. (2003). Bring on German Cost Accounting. Strategic Finance, 85(6), 30-38. 